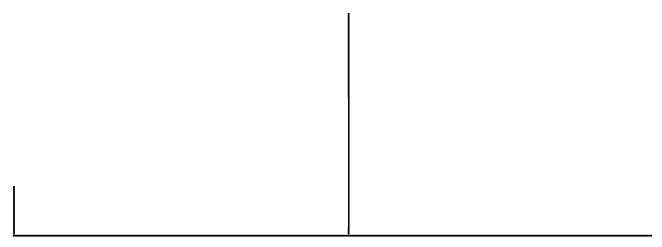

Rev. Latinoam. Psicopat. Fund., São Paulo, v. 15, n. 1, p. 42-57, março 2012

\title{
A dimensional approach to personality disorders in a sample of juvenile offenders
}

Daniela Cantone

Raffaele Sperandeo

Mauro Maldonato

In a sample of 60 male Italian subjects imprisoned at a juvenile detention institute (JDI), psychopathological aspects of the AXIS II were described and the validity of a psychopathological dimensional approach for describing criminological issues was examined. The data show that the sample has psychopathological characteristics which revolve around ego weakness and poor management of relations and aggression. Statistically these psychopathological characteristics explain $85 \%$ of criminal behavior.

Key words: Personality disorders, juvenile offenders, dimensional approach, criminological issues 


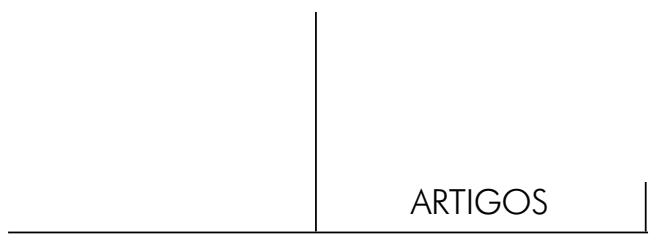

\section{Introduction}

Epidemiological studies in western populations display a frequency of Personality Disorders (PDs) among adult offenders ranging between 40 per cent and 90 per cent (Casey, 2000; Hiscoke, Langstrom, Ottosson, \& Grann, 2003). Although subject to varying interpretations, an undisputed link between crime and pathological personality traits emerges from these samples. However, these studies were based on adult populations and the data is not automatically applicable to juvenile offenders, due to the complexity of psychopathology in adolescence and the specific issues involved. The studies regarding pathologic personality traits among juvenile offenders confirmed the association between personality disorders and criminal behavior. Coles, Greene \& Braithwaite (2002) found a high frequency of paranoid and psychopathic traits among juvenile offenders. Using similar samples, Connor, Carlson, Chang, Daniolos, Ferziger, Findling, Hutchinson, Malone, Halperin, Plattner, Post, Reynolds, Rogers, Saxena \& Steiner (2006) described two correlation models: on the one hand, a link emerged between the pathological internalization of anger, "neuroticism" and impulsive violence; on the other hand, there was also a link between the pathological externalization of anger and the tendency to carry out more serious crimes. Given the current evidence, it is impossible to decide whether pathologic personality traits play a role in the development of criminal behavior or whether crime and the personality disorders are the outcome of common processes such as parental neglect, living in a criminal environment and genetic liability. (Krischer, Sevecke, Lehmkuhl \& Pukrop, 2007). With regard to the studies of juvenile offenders, indices of aggression show a strong correlation with criminal behavior in adulthood and suggest the need to focus on the dimensional constructs of personality which may be predictive factors of the inclination to commit crime (Moffitt, Caspi, Harrington, \& Milne, 2002; Moffitt, 2003; Dodge, 2003). In 2001, an expert committee of the American Psychiatric Association and the National Institute of Mental Health emphasized the importance of developing a dimensional model of personality disorders in order to obtain effective diagnostic measures 
(Rounsaville, Alarcon, Andrews, Jackson, Kendell, \& Kendler, 2002) as well as to improve the quality of treatment (Verheul, 2005). The DSM-V Research Agenda, especially regarding Axis II, seems to move to a dimensional or mixed model (Widiger, Simonsen, Krueger, Livesley, \& Verheul, 2005; Widiger, Livesley, \& Clark, 2009; Widiger, 2007; Widiger \& Lowe, 2008; Mullins-Sweatt, Smith, Verheul, Oldham, \& Widiger, 2009). Compared to the diagnostic categories, dimensional models display a higher degree of reliability (Livesly, 2003; Livesley, Schroeder, Jackson, \& Jang, 1994; Trull \& Durrett, 2005; Widiger et al. 2005). It is possible to see similarities in the factorial structure of the personality traits, both in the samples of patients and in the general population. The seriousness of the symptoms increases proportionally to the intensity of expression of the trait without any evidence of discontinuity, and the reliability and stability of the structures are higher compared to the category diagnosis. Skodol, Oldham, Bender, Dyck, Stout, Morey, Shea, Zanarini, Sanislow, Grilo, McGlashan, \& Gunderson (2005) have highlighted that the diagnostic criteria that constitute the PD in the DSM IV have a higher clinical validity compared to the PD itself, especially considering the fact that they are long-lasting. Furthermore, these criteria have a high correlation with dimensional personality models, such as the Five Factor Model (FTM). According to some authors, the classification of the DSM could continue to define the framework of categories that are clinically important, within which a map of the personality dimensions could be traced; this would protect both the generalizing validity of the diagnostic categories and the power of the traits as descriptors of the individual specificities. In this way, continuity can be preserved with the psychiatric tradition, which in itself is simple and efficient when referring to clinical classification: at the same time, however, complex variables could be introduced which could offer a significant contribution to forms of treatment which would be supported both by psychopathology and neurobiology (First, 2005). Our study was carried out on a teenage population in a Juvenile Detention Institute (JDI) in the Italian region of Campania; the goals of the research were to define the description of the psychopathological aspects of AXIS II and to propose a psychopathological dimensional approach to describing the criminological peculiarities of this sample.

\section{Material and methods}

The participants were 60 Italian males imprisoned in a Juvenile Detention Institute (JDI) in the Italian region of Campania, aged between 16 and 18 years old $(\mathrm{M}=17.17, \mathrm{SD}=0.7)$. The 60 subjects received sentences ranging between 


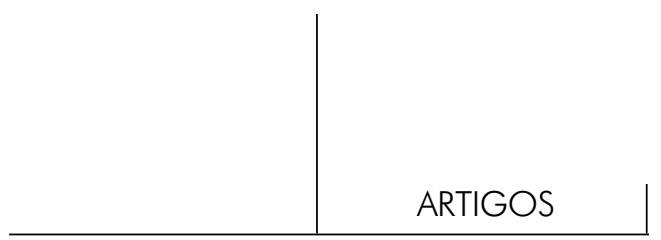

21 and 306 months $(M=108.72 \mathrm{SD}=69.9) .80 .9 \%$ of the participants $(\mathrm{N}=48)$ committed crimes against the person (4 of them committed murder) and can be defined as "violent offenders" (McGlashan, Grilo, Skodol, Gunderson, Shea, Morey, Zanarini, \& Stout, 2000). 25.5\% of the subjects $(\mathrm{N}=15)$ had been convicted for two or more crimes. $6.7 \%(\mathrm{~N}=4)$ had no formal education, $46.7 \%$ $(\mathrm{N}=28)$ had a primary school certificate and $46.7 \%(\mathrm{~N}=28)$ had a junior high school certificate. Many of them have acquired the qualification during their stay in the JDI. The diagnostic assessment was carried out using the Structured Clinical Interview for DSM (SCID II) (Spitzer, Williams, Gibbon, \& First, 1990), which enables a PD diagnosis to be made according to the DSM-III-R criteria, and the State Trait Anger Expression Inventory (STAXI) (Spielberg, 1988), which measures anger management.

The SCID-II was used to diagnose Personality Disorders (AXIS II of the DSM) from the point of view of categories (present or absent). It consists of 113 items and a score of " 3 " on an item indicates that the characteristic described in the item is "pathological", "persistent" and "widespread". The interview was carried out by three trained researchers who achieved an elevated inter-rater reliability $(\mathrm{k}=0,84)$.

The STAXI assesses the components and the ways of coping with anger. This instrument consists of 44 items, which form six scales and two sub-scales. The six scales are: State Anger (S-anger, Trait Anger (T-anger), Anger directed inwards (Anger-In), Anger directed outwards (Anger-Out), Anger control (Angercon), Anger expression (anger-ex). There are two subscales in the T-anger scale: Temperament inclined to anger (T-anger/T) and Anger reactions (T-anger/R).

The subjects were informed of the research aims and it was explained to them that the assessments would not have any bearing on their cases. Furthermore, anonymity was guaranteed by an alphanumeric code known only to the JDI operators. Before accessing the assessment, the subjects underwent a psychiatric visit to exclude acute psychopathological conditions or chronic Axis I within the areas of affective or psychotic disorders, a history of clinically significant head injuries, and, finally, drug abuse in the last month. The sociodemographic background and the individual cases of the subject data were made available through the operators of the Detention Institute. As a first step, we described the socio-demographic characteristics, the frequency of personality disorders, the anger management of the subjects and the correlation between these variables and criminological characteristics. Secondly, the linear regression analysis performed with the stepwise method made it possible to construct a model in which the items of the DSM-IV for Axis II disorders were treated as explanatory variables and the months of the sentence were the dependent variable(s) (Ryder et al., 2007). The months of the sentence reflect both the severity and number 
of committed crimes. This method allowed us to organize a "dimension of symptoms" (Goldberg \& Goodyer, 2005), fifteen diagnostic criteria for Axis II of DSM-IV which can be considered significant elements for the development of criminal behavior. Lastly, the 15 criteria were correlated with the criminological characteristics and the STAXI scales in order to identify the specific items considered most appropriate for explaining the crime patterns.

Results

Of the 60 subjects, only $1(1.7 \%)$ does not fulfill any PD criteria, while 49 subjects $(81.7 \%)$ have two or more PDs. The most common diagnosis is Conduct Disorder $(\mathrm{CD})$, found in $74.6 \%$ of subjects $(\mathrm{N}=45)$, followed by the subtype diagnoses Paranoid (PPD) (45.8\% - $\mathrm{N}=27)$, Obsessive-Compulsive (OCPD) $(40.7 \%-\mathrm{N}=24)$, Borderline (BPD) $(40.7 \%-\mathrm{N}=24)$, Narcissistic (NPD) $(35.6 \%-\mathrm{N}=21)$ and Avoidant (APD) $(30.5 \%-\mathrm{N}=18)$. There was no correlation between the Axis II diagnosis, the criminological variables and criminal type. Given the age of the subjects, who are mostly minors, it was considered preferable to make a diagnosis of Conduct Disorder rather than of Antisocial Personality Disorder. The scores obtained from the STAXI show an overall difficulty in controlling anger, and an impulsive mode in the management of aggression. $20.7 \%$ of subjects $(\mathrm{N}=12)$ achieved pathological scores on the trait anger scale (T-Anger); $32.8 \%$ of subjects $(\mathrm{N}=20)$ achieved pathological scores on the scale that measures the frequency with which angry feelings are preserved or erased $(\mathrm{AX} / \mathrm{In}) ; 25.9 \%(\mathrm{~N}=16)$ achieved pathological scores on the scale that measures the individual frequency of expressing anger towards other people or objects of the environment (AX/Out); lastly, 36.2\% of subjects $(\mathrm{N}=22)$ had pathological anger management (AX/EX). The scale of the Anger State (which documents the emotional condition at the time of the administration of the test) is high for only $3.5 \%$ of subjects $(\mathrm{N}=2)$. This value was explained by the effect of emotional containment that the rules applied in the detention regime have on the people concerned. The Anger Turned Inward scale (AX/In) correlates negatively with the months of sentence received ( $r h o=-.36 \mathrm{p}=.01$ ). This figure, which is indicative of a medium-low correlation of the link between anger and the severity and frequency of criminal behavior, showed a protective value for introverted anger management. The diagnosis of Conduct Disorder correlated positively with the STAXI scales Trait Anger (rho $=.40 \mathrm{p}=.001$ ), Reactive Trait Anger (rho $=.27 \mathrm{p}=.04)$, Outward Anger (rho $=.29 \mathrm{p}=.03$ ), Anger Overall Pathological (rho $=.26 \mathrm{p}=.05)$ and negatively with the scale of Anger Control (rho $=-.32 \mathrm{p}=.02)$. The diagnosis of Borderline Personality Disorder correlates positively with the State Anger Scale (rho $=.32 \mathrm{p}=.01$ ). The diagnosis of Avoidant Personality Disorder correlates negatively with the overall pathological 
anger scale ( $r$ ho $=-.28 \mathrm{p}=.03$ ). The data describes a sample characterized by a specific psychopathological mode centered on impulsivity and on the poor management of aggression, both in the sense of introversion and extroversion. From the linear regression tests, where the months of sentence received by subjects represented the dependent variable and the Axis II diagnostic criteria of DSM IV were the explanatory variables, various factors emerged that can predict the severity of criminal conduct; these included three NPD and APD criteria, two CD and IPD criteria and only one OCDP, DPD, PPD, BPD and STPD criterion. Some items result in a negative variation of the regression, as indicated by the negative value of $\mathrm{B}$; this can be expected to show a lower severity of criminal behavior among individuals for whom this item was found. The regression model, taken as a whole, (rho square $=.85$ ) indicates that $85 \%$ of the variance of the number of sentence months received by the subjects is explained by its linear relationship with the 15 items of which the model is made up (Table 1).

Table 1

Linear regression model explanatory variables: item DSM-IV Axis II. (Dependent variable: Months of sentence received)

\begin{tabular}{|c|c|c|c|c|c|c|}
\hline ITEM AXIS II DSM IV & B & b & $\mathbf{p}$ & $\mathbf{R}^{2}$ & $\mathbf{F}$ & $\mathbf{P}$ \\
\hline $\begin{array}{l}\text { IPD consistently uses physical appearance to } \\
\text { draw attention to himself }\end{array}$ & 87.06 & 0.55 & 0.00 & & & \\
\hline $\begin{array}{l}\text { NPD he lacks empathy: is unable to recognize } \\
\text { or identify with the feelings and needs of others }\end{array}$ & 44.49 & 0.28 & 0.00 & & & \\
\hline $\begin{array}{l}\text { DPN he has the feeling that he is automatically } \\
\text { entitled to everything, unreasonable expectations } \\
\text { of favorable treatment or immediate satisfaction } \\
\text { of his expectations }\end{array}$ & -28.32 & -0.20 & 0.01 & & & \\
\hline $\begin{array}{l}\text { OCDP indecision, the decisions taken shall be } \\
\text { avoided, postponed, prolonged. The individual } \\
\text { cannot complete his commitments on time due } \\
\text { to pondering different priorities }\end{array}$ & 63.46 & 0.43 & 0.00 & & & \\
\hline $\begin{array}{l}\text { DDP he has difficulty making everyday decisions } \\
\text { without requiring an excessive amount of } \\
\text { advice and reassurance }\end{array}$ & -80.25 & -0.53 & 0.00 & 0.85 & 18.09 & 0.00 \\
\hline $\begin{array}{l}C D \text { he has stolen while coming face-to-face } \\
\text { with the victim }\end{array}$ & -65.86 & -0.47 & 0.00 & & & \\
\hline $\begin{array}{l}\text { APD he is inhibited in intimate relationships for } \\
\text { fear of being humiliated or ridiculed }\end{array}$ & -29.90 & -0.21 & 0.00 & & & \\
\hline
\end{tabular}




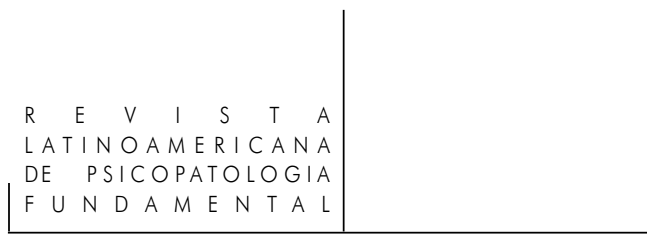

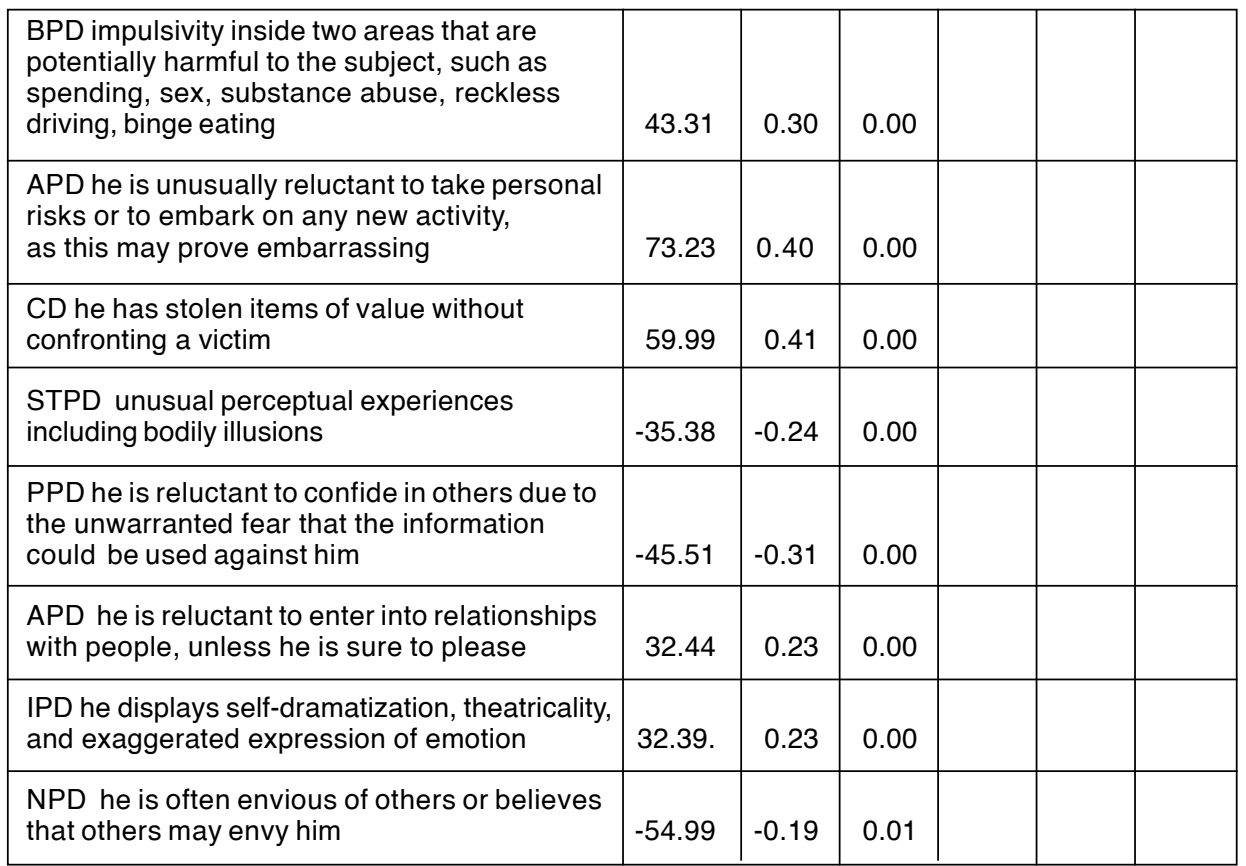

The two items relating to Conduct Disorder have not been included in subsequent evaluations since they define the behaviors (theft, and robbery with assault on the victim) and, as such, are not equivalent to personality traits. The 13 remaining items identified by the regression model were correlated with the criminological characteristics and the STAXI scales. Three items (lacks empathy: he is unable to recognize or identify himself with the feelings and needs of others - he is reluctant to enter into relationships with people, unless he is sure to please - he consistently uses physical appearance to attract attention to himself) were related to the criminological variables and one of them was also linked to the two STAXI scales. One item (unusual perceptual experiences, including bodily illusions) was negatively correlated with the criminological variables. For 29 subjects $(48.33 \%)$ one or more of three items was/were positively correlated to the criminological variables, for 7 subjects $(11.67 \%)$ the item was negatively correlated to the criminological variables, 13 subjects $(21.67 \%)$ had both a positively and negatively related item, while 11 subjects $(18.33 \%)$ did not have any of the above items (Table 2). 


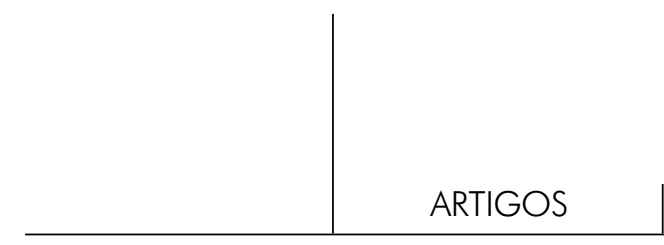

Table2

Correlation:itemsofregressionmodelvs.criminologicalvariables

\begin{tabular}{|l|c|}
\hline \multicolumn{1}{|c|}{ Items } & Criminological Variables \\
\hline \hline $\begin{array}{l}\text { He lacks empathy: is unable to recognize or identify } \\
\text { with the feelings and needs of others (NPD) }\end{array}$ & $\begin{array}{c}\text { Number of crimes } \\
(p=.32, p=.03)\end{array}$ \\
\hline $\begin{array}{l}\text { He is reluctant to enter into relationships with } \\
\text { people, unless he is sure to please (APD) }\end{array}$ & $\begin{array}{c}\text { Number of crimes } \\
(p=.40, p=.01)\end{array}$ \\
\hline $\begin{array}{l}\text { he consistently uses physical appearance to } \\
\text { draw attention to himself (IPD) }\end{array}$ & $\begin{array}{c}\text { Seriousness of the offenses } \\
(p=.43, p=.001)\end{array}$ \\
\hline $\begin{array}{l}\text { unusual perceptual experiences including } \\
\text { bodily illusions (STPD) }\end{array}$ & $\begin{array}{c}\text { Total months of sentence } \\
(p=.30, p=.04)\end{array}$ \\
\hline
\end{tabular}

Subjects who had one or more items positively correlated with criminal behavior committed more serious crimes such as murder, and therefore fall into the "violent offender" category. Those who have only one negatively correlated item commit less serious crimes (Table 3).

\section{Table3}

Criminological characteristics explained by the items of the regression model

\begin{tabular}{|l|c|c|c|c|}
\hline Subjects & $\begin{array}{c}\text { Violent } \\
\text { offender }\end{array}$ & Murders & $\begin{array}{c}\text { Two or more } \\
\text { crimes }\end{array}$ & $\begin{array}{c}\text { Months of } \\
\text { sentence }\end{array}$ \\
\hline \hline $\begin{array}{l}\text { Subjects who have one or more } \\
\text { items positively correlated with } \\
\text { criminological variables }\end{array}$ & 20 & 4 & 8 & 134.15 \\
\hline $\begin{array}{l}\text { Subjects who have an item } \\
\text { negatively correlated with } \\
\text { criminological variables }\end{array}$ & 1 & 0 & 0 & 40.20 \\
\hline & $\begin{array}{c}\chi^{2}=9.84 \\
\mathrm{P}<.01\end{array}$ & $\begin{array}{c}\chi^{2}=12.05 \\
\mathrm{P}<.05\end{array}$ & $\begin{array}{c}\chi^{2}=2.44 \\
\text { P n.s. }\end{array}$ & $\begin{array}{c}\mathrm{F}=6.42 \\
\mathrm{P}<.05\end{array}$ \\
\hline
\end{tabular}




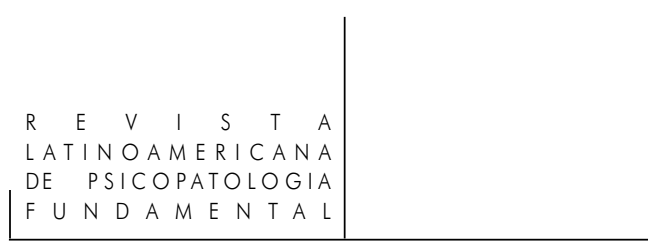

\section{Discussion}

Most subjects have at least one Personality Disorder, with a high frequency of Conduct Disorder and Narcissistic, Avoidant, Paranoid and Borderline disorders. Many subjects have three or more disorders in co-morbidity. This figure, which is in line with the findings in the literature, demonstrates the marked clinical impairment of these subjects but provides no model for understanding their psychopathological and criminological characteristics. The excessive co-morbidity among the AXIS II disorders significantly diminishes the practical utility of the categorical model used to identify the psychopathological elements that are necessary to describe the examined subjects. This leads to problems in setting up a personalized treatment program or may even make it impossible. Among the subjects making up the sample, personality disorders seem to be based on a difficulty in managing the aggressive emotions that have become uncontrollably extroverted or blocked in a social withdrawal mode, as appears when applied to the specific STAXI scales. Neither the DSM Axis II categories nor the STAXI scales enabled a clinical profile to be drawn up that was suitable for identifying the risk of acting out criminal behavior. Using the DSM criteria individually has proved useful for correlating personality traits with the severity of criminal behavior. The presence of 15 items of Histrionic, Narcissistic, Borderline, Avoidant, ObsessiveCompulsive, Conduct Disorder, Paranoid and Schizotypal disorders may account for the implementation of more frequent and severe criminal conduct. Of these 15 items, two are not equivalent to character traits because they express criminal behavior carried out during preadolescence. Three items linked to the relational aspects of the narcissistic, histrionic and avoidant disorders are present in subjects classified as "violent offenders" and therefore characterized by more serious criminal careers; one DSTP item that expresses a serious impairment of the ego integrity is present in those with less serious criminal conduct. Overall, the data shows that the sample has psychopathological characteristics that revolve around the weakness of the Ego and the poor management of relations and aggression. Statistically, these psychopathological characteristics explain $85 \%$ of criminal behavior while the remaining $15 \%$ could be explained by the fact that individuals live in highly criminogenic social contexts. More specifically, the management of pathological anger does not have significant effect on the implementation of criminal behavior; the Ego pathology seems to be protective with regard to the development of particularly cruel actions while the alteration of social skills is the crucial element in criminal conduct during adolescence. Work that has led to similar conclusions has been carried out by Atarhouch, Hoffmann, Adam, Titeca, Stillemans, Fossion, Le Bon \& Servais (2004), using the seven 


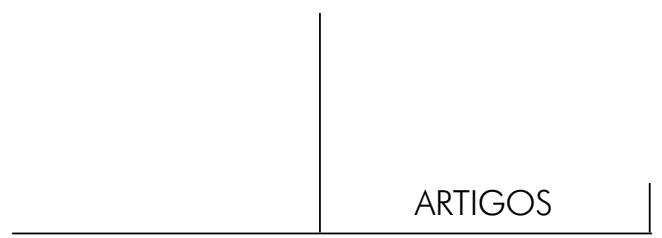

factor model of Cloninger (1987; Cloninger, Svrakic \& Przybeck, 1993, Cloninger, Przybeck, Svrakic \& Wetzel, 1994) have identified low scores in the cooperative ability of a group of teenage criminals compared to a control sample of adolescents. Moreover, if compared with the internalization/externalization model (Krueger, 1999 e 2005; Krueger, Hicks, Patrick, Carlson, Iacono \& McGue, 2002), our data suggests the existence of a latent trait capable of explaining the seriousness of criminal behavior which consists of protective elements belonging to the internalization area and risk elements belonging to the externalization area (Goldberg \& Goodyer, 2005). Lastly, in the psychodynamic interpretation, the symptoms of anaclitic depression, which are developed through an impairment of object relations, seem to lie behind the criminogenic tendencies (Blatt 1990; Blatt, Hart, Quinlan, Leadbeater \& Auerbach, 1993; Blatt, Auerbach, Zuroff \& Shahar, 2006; Blatt, \& Luyten, 2009; Blatt \& Shichman, 1983). These traits supply an individualized, dimensional description of each subject which is closer to the quality of the clinical observation and more useful for evaluating the symptoms in a dichotomized manner. Our subjects are not "impulsive" or "nonimpulsive"; they express this trait in a more or less intensive manner, and the quantitative individual difference is fundamental for deciding the clinical and therapeutic priorities. Furthermore, the traits derive from the psychiatric clinical tradition, and are easy to understand and manage for clinical personnel who are traditionally used to structures and contents that the traits themselves express. The methodological limitation of the study regards the small sample size. The research is designed to be a pilot study which needs significantly more data and an extension of the model to samples of non-detained adolescents and adolescents belonging to a population who are at a risk of delinquency. This is necessary in order to generalize the psychopathological ideas and to formulate a predictive model of criminal behavior during adolescence. Nevertheless, the dimension of the symptoms obtained through the regression model can provide an individualized description of each subject which is closer to the characteristics of clinical observation and more useful than the dichotomous diagnosis. This may be useful for predicting the severity of criminal recidivism and for organizing more effective rehabilitation programs. The advantage of this model is linked to the fact that a small number of items effectually describe the individual psychopathology and are suitable for predicting criminal behavior. The evaluation of predictive factors is obviously much more complex and should take into account the interaction between the individual and the environment (Farrington, Jolliffe, Loeber, Stouthamer-Loeber \& Kalb, 2001; Nagin \& Tremblay, 2001; Tremblay, 2003). 


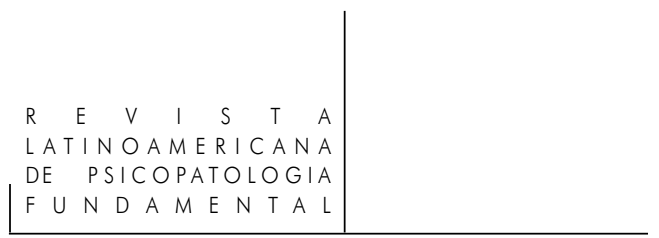

\section{References}

American Psychiatric Association. DSM-IV-TR: Diagnostic and Statistical Manual of Mental Disorders. 4th ed. revised. Washington, DC: American Psychiatric Association, 2000

Atarhouch, N.; Hoffmann, E.; Adam, S.; Titeca, J.; Stillemans, E.; Fossion, P.; Le Bon, O.; Servais, L. Evaluation of typical psychopathic traits with juvenile offenders. Encephale, v. 30, n. 4, p. 369-375, Jul-Aug.2004 .

BLATT, S.J. Interpersonal relatedness and self-definition: Two personality configurations and their implication for psychopathology and psychotherapy. In: SINGER, L.J. Repression and Dissociation: Implications for Personality Theory, Psychopathology and Health. University of Chicago Press, Chicago, 1990. p. 299335 .

Blatt, S.J.; Auerbach, J.S.; Zuroff, D.C.; Shahar, G. Evaluating efficacy, effectiveness, and maturative factors in psychodynamic psychotherapies. In: PMD TASK FORCE. Psychodinamic Diagnostic Manual. Silver Spring, MD: Alliance of Psychoanalytic Organizations, 2006. p. 446-475.

Blatt, S.J.; Hart, B.; Quinlan, D.M.; Leadbeater, B.; Auerbach, J. Interpersonal and self-critical dysphoria and behavioural problems in adolescents. Journal of Youth and Adolescence, n. 22, p. 253-269, 1993.

Blatt, S.J.; LuYten, P. A structural-developmental psychodynamic approach to psychopathology: two polarities of experience across the life span. Development and psychopathology, v. 21, n. 3, p. 793-814, 2009.

Blatt, S.J.; Shichman, S. Two primary configurations of psychopathology. Psychoanalysis and Contemporary Thought, n. 6, p. 187-254, 1983.

Casey, P. (2000). The epidemiology of personality disorders. In: Tyrer, P. (Ed.). Personality disorders: Diagnosis, mangement and course. London: Arnold, 2000. p. 71-79. Cloninger, C.R.; Przybeck, T.R.; Svrakic, D.M.; Wetzel, R.D. The Temperament and Character Inventory (TCI): a guide to its development and use. St. Louis, Missouri: Center for Psychobiology of Personality, 1994.

Cloninger, C.R., Svrakic, D.M.; Przybeck, T.R. A psychobiological model of temperament and character. Archives of General Psychiatry, n. 50, p. 975-990, 1993.

Cloninger, C.R. A Systematic Method for Clinical Description and Classification of Personality Variants. Archives of General Psychiatry, n. 44, p. 573-588, 1987.

Coles, C.J.; Greene, A.F.; Braithwaite, H.O. The relationship between personality, anger expression, and perceived family control among incarcerated male juveniles. Adolescence, v. 37, n. 146, p. 395-409, 2002. 


\section{ARTIGOS}

Connor, D.F.; Carlson, G.A.; Chang, K.D.; Daniolos, P.T.; Ferziger, R.; Findling, R.L.; Hutchinson, J.G.; Malone, R.P.; Halperin, J.M.; Plattner, B.; Post, R.M.; ReYnolds, D.L.; Rogers, K.M.; SAXENA, K.; Steiner, H. Juvenile maladaptive aggression: a review of prevention, treatment, and service configuration and a proposed research agenda. The Journal of clinical psychiatry, v. 67, n. 5, p. 808-20, 2006.

DodGe, K.A. (2003). A biopsychosocial model of the development of chronic conduct problems in adolescence. Developmental psychology, v. 39, n. 2, p. 349-371, 2003.

Farrington, D.P.; Jolliffe, D.; Loeber, R.; Stouthamer-Loeber, M.; Kalb, L. The concentration of offenders in families, and family criminality in the prediction of boys' delinquency. Journal of Adolescence, n. 24, p. 579-596, 2001.

FIRST, M.B. Clinical utility: a prerequisite for the adoption of a dimensional approach in DSM. Journal of abnormal psychology, v. 114, n. 4, p. 560-564, 2005.

Golberg, D.; Goodyer, I. The Origins and Course of Common Mental Disorders. London, UK: Psychology Press, 2005.

Hiscoke, U.L.; Langstrom, N.; Ottosson, H.; Grann, M. Self-reported personality traits and disorders (DSM-IV) and risk of criminal recidivism: A prospective study. Journal of Personality Disorders, n. 17, p. 293-305, 2003.

Kernberg, O.F. Severe Personality Disorders. Psychotherapeutic Strategies. New Haven, CT: Yale Univ. Press, 1984.

Krischer, M.K.; Sevecke, K.; Lehmkuhl, G.; Pukrop, R. Dimensional assessment of personality pathology in female and male juvenile delinquents. Journal of Personality Disorders, v. 21, n. 6, p. 675-89, Dec.2007.

KRUEGER, R.F. Continuity of Axes I and II: Toward a unified model of personality, personality disorders, and clinical disorders. Journal of Personality Disorders, n. 19, p. 233-261, 2005.

Krueger, R.F.; Hicks, B.M.; Patrick, C.J.; Carlson, S.R.; Iacono, W.G.; McGue, M. Etiologic connections among substance dependence, antisocial behaviour, and personality: Modeling the externalizing spectrum. Journal of Abnormal Psychology, n. 111, p. 411-424, 2002.

Krueger, R.F. The structure of mental disorders. Archives of General Psychiatry, n. 56, p. 921-926, 1999.

Livesley, W.J. Diagnostic dilemmas in classifying personality disorder In: K.A. Phillips; M.B. First; H.A. Pincus (Eds.). Advancing DSM. Dilemmas in psychiatric diagnosis. Washington, DC: American Psychiatric Association, 2003. p. 153-190.

Livesley, W.J.; Schroeder, M.L.; Jackson, D.N.; JANG, K.L. Categorical distinctions in the study of personality disorder: implications for classification. Journal of Abnormal Psychology, v. 103, n. 1, p. 6-17, 1994. 
McGlashan, T.H.; Grilo, C.M.; Skodol, A.E.; Gunderson, J.G.; Shea, M.T.; Morey, L.C.; Zanarini, M.C.; Stout, R.L. The Collaborative Longitudinal Personality Disorders Study: baseline Axis I/II and II/II diagnostic co-occurrence. Acta Psychiatryca Scandinavica, v. 102, n. 4, p. 256-264, 2000.

MoffitT, T.E. Life-course-persistent and Adolescence-limited antisocial behaviour: A 10-year research review and a research agenda. In: LAhey, B.; Moffitt, T.E.; CASPI, A. (Eds.). Causes of Conduct Disorder and Juvenile Delinquency. New York: Guilford, 2003.

Moffitt, T.E.; Caspi, A.; Harrington, H.; Milne, B. Males on the life-course persistent and adolescence-limited antisocial pathways: Follow-up at 26 age. Development and Psychopathology, n. 14, p. 179-206, 2002.

Mullins-Sweatt, S.N.; Smith, V.; Verheul, R.; Oldham, J.; Widiger, T.A. Dimensions of personality: clinicians' perspectives. Canadian Journal of Psychiatry, v. 54, n. 4, p. 247-259, 2009.

Nagin, D.S.; Tremblay, R.E. Analyzing developmental trajectories of distinct but related behaviours: A group-based method. Psychological Methods, v. 6, 1: 18-34, 2001.

Rounsaville, B.J.; Alarcon, R.D.; Andrews, G.; Jackson, J.S.; Kendell, R.E.;

KendLer, K. Basic nomenclature issues for DSM-V In: D.J. KuPfer, M.B. FIRST AND

D.E. Regier (Eds.). A research agenda for DSM-V. Washington, DC: American Psychiatric Association, 2002. p. 1-29.

Ryder, A.G.; Costa, P.T.; BAGBy, R.M. Evaluation of the SCID-II personality disorder traits for DSM-IV: coherence, discrimination, relations with general personality traits, and functional impairment. Journal of Personality Disorders, v. 21, n. 6, p. 626-637, 2007.

Skodol, A.E.; Oldham, J.M.; Bender, D.S.; Dyck, I.R.; Stout, R.L.; Morey, L.C.; Shea, M.T.; Zanarini, M.C.; Sanislow, C.A.; Grilo, C.M.; McGlashan, T.H.; Gunderson, J.G. Dimensional representations of DSM-IV personality disorders: relationships to functional impairment. American Journal of Psychiatry, n. 162, p. 1919-1925, 2005.

SPIELBerg, C.D. Manual for the State-Trait Anger Expression Inventory (STAXI). Odessa, FL: Psychological Assessment Resources, 1988.

Spitzer, R.L.; Williams, J.B.W.; GibBon, M.; First, M.B. (1990). The Structured Clinical Interview for DSM-III-R Axis II Disorders (SCID-II). American Psychiatric Press, Washington, USA.

TREMBLAY, R.E. Why socialization fails: the case of cronic physical aggression. In: Lahey, B.; Moffitt, T.E.; CASPI, A. (a cura di). Causes of Conduct Disorder and Juvenile Delinquency. New York: The Guilford Press, 2003. 


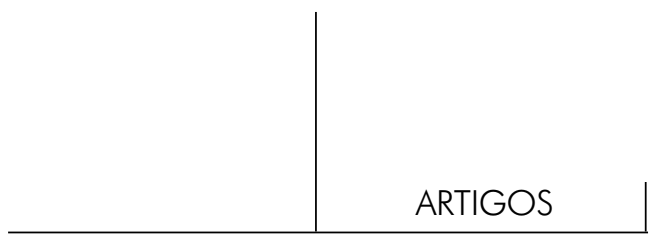

Trull, T.J.; Durrett, C.A. Categorical and dimensional models of personality disorder. Annual Review of Clinical Psychology, n. 1, p. 355-80, 2005.

Verheul, R. Clinical utility of dimensional models for personality pathology. Journal of Personality Disorders, v. 19, n. 3, p. 283-302, 2005.

Widiger, T.A. Dimensional models of personality disorder. World Psychiatry, v. 6, n. 2, p. 79-83, 2007.

Widiger, T.A.; Livesley, W.J.; Clark, L.A. An integrative dimensional classification of personality disorder. Psychological assessment, v. 21, n. 3, p. 243-55, 2009.

Widiger, T.A.; LowE, J.R. (2008). A dimensional model of personality disorder: proposal for DSM-V. The Psychiatric clinics of North America, v. 31, n. 3, p. 363-378 .

Widiger, T.A.; Simonsen, E.; Krueger, R.; Livesley, W.J.; Verheul, R. Personality disorder research agenda for the DSM-V. Journal of Personality Disorders, v. 19, n. 3, p. 315-338, 2005.

\begin{abstract}
(Uma abordagem dimensional a distúrbios de personalidade em uma amostra de menores infratores)

Em uma amostra de 60 sujeitos italianos do sexo masculino presos em un instituto de detenção para menores (JDI), descreveram-se os aspectos psicopatológicos do Axis II e examinou-se a validade de uma abordagem de dimensão psicopatológica para a descrição das questões criminológicas.

No conjunto, os dados apontam que a amostragem apresenta características psicopatolócas que dizem respeito à debilidade do Ego e a uma má gestão das relações e da agressão. Estatísticamente, essas características psicopatológicas explicam $85 \%$ do comportamento criminal.

Palavras-chave: Distúrbios da personalidade, menores delinquentes, abordagem pluridimensional, questões

(Une approche dimensionnelle aux troubles de la personnalité dans un échantillon de mineurs délinquants)

Un échantillon de 60 sujets italiens de sexe masculin détenus dans un établissement pénitentiaire pour mineurs (JDI) nous a servi de base pour décrire les aspects psychopathologiques de l'Axe II et pour examiner la validité d'une approche à dimensions psychopathologique pour décrire les questions criminologiques.
\end{abstract}


Dans l'ensemble, les données indiquent que l'échantillon présente des caractéristiques psychopathologiques qui relèvent de la faiblesse de l'ego et de la mauvaise gestion des relations et de l'agression. Statistiquement, ces caractéristiques psychopathologiques expliquent à $85 \%$ le comportement criminel.

Mots clés: Troubles de la personnalité, mineurs délinquants, approche pluridimensionnelle, questions criminologiques

(Un abordaje dimensional de los trastornos de personalidad en una muestra de delincuentes juveniles)

En una muestra compuesta por 60 sujetos italianos de sexo masculino encarcelados en un instituto correccional para jóvenes (ICJ), se hizo la descripción de los aspectos psicopatológicos de los trastornos de personalidad (AXIS II) y se examinó la validez del abordaje dimensional psicopatológico para describir las cuestiones criminológicas.

Los datos demuestran que la muestra tiene características psicopatológicas que giran alrededor de la debilidad del ego y de gestión deficiente de las relaciones y de la agresión. Estadísticamente, esas caracteristicas psicopatológicas explican el $85 \%$ del comportamiento criminal.

Palabras clave: Trastorno de personalidad, criminales juveniles, abordaje dimensional, cuestiones criminológicas

(Dimensionaler Ansatz von Persönlichkeitsstörungen am Beispiel krimineller Jugendlicher)

Am Beispiel von 60 italienischen männlichen Personen, die in einer Haftanstalt für Minderjährige sitzen, wurden psychopathologische Aspekte der Achse-II-Störungen (Persönlichkeitsstörungen) beschrieben und die Validität eines Ansatzes mit psychopathologischer Dimension zur Beschreibung der kriminalistischen Fragen untersucht.

Zusammengenommen, deuten die Angaben darauf hin, dass die Beispiele psychopathologische Eigenschaften aufweisen, welche in Zusammenhang mit einem labilen Ego und mangelhafter Pflege der Beziehungen sowie Umgangsschwierigkeiten mit Aggression stehen. Statistisch gesehen erklären diese psychopathologischen Aspekte $85 \%$ des kriminellen Verhaltens.

Schlüsselwörter: Persönlichkeitsstörungen, kriminelle Jugendliche, pluridimensionaler Ansatz, Fragen

Citação/Citation: Cantone, D.; Sperandeo,R.; Maldonato, M. A dimensional approach to personality disorders in a sample of juvenile offenders. Revista Latinoamericana de Psicopatologia Fundamental, São Paulo, v. 15, n. 1, p. 42-57, mar.2012. 


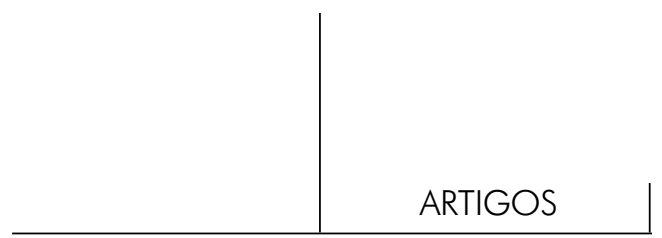

Editor do artigo/Editor: Prof. Dr. Manoel Tosta Berlinck

\section{Recebido/Received: 18.1.2011 / 1.18.2011 Aceito/Accepted: 28.1.2011 / 1.28.2011}

Copyright: () 2009 Associação Universitária de Pesquisa em Psicopatologia Fundamental/ University Association for Research in Fundamental Psychopathology. Este é um artigo de livre acesso, que permite uso irrestrito, distribuição e reprodução em qualquer meio, desde que o autor e a fonte sejam citados/This is an open-access article, which permits unrestricted use, distribution, and reproduction in any medium, provided the original author and source are credited.

Financiamento/Funding: Os autores declaram não ter sido financiados ou apoiados/The authors have no support or funding to report.

Conflito de interesses/Conflict of interest: Os autores declaram que não há conflito de interesses/The authors declare that has no conflict of interest.

\section{Daniela Cantone}

Departament of Psychology, University of Naples SUN, Italy.

Via Vivaldi 43

81100 Caserta, Italy

e-mail: daniela.cantone@unina2.it

\section{RafFaele Sperandeo}

SiPGI - School of Gestalt Psychotherapy Integrated, Italy.

Via Dante, 1/D

80058 Torre Annunziata (NA)

Italy

e-mail: raffaele.sperandeo@gmail.com

\section{Mauro Maldonato}

Department of Historical, Linguistic and Anthropological Science, University of Basilicata, Italy.

Largo Caterina Volpicelli all Salute, 5

80136 Napoli, Italia

e-mail: mauromaldonato@fastwebnet.it 